\title{
Biomass of elephant grass and leucaena for bioenergy production
}

\section{Biomassa de capim elefante e leucena para produção de bioenergia}

\author{
Fernanda Aparecida Sales ${ }^{1 *}$; Paulo Henrique Caramori ${ }^{2}$; Wilian da Silva Ricce ${ }^{3}$; \\ Marco Aurélio Teixeira Costa ${ }^{4}$ Geovanna Cristina Zaro ${ }^{1}$
}

\begin{abstract}
The objective of this study was to evaluate the biomass production of elephant grass and leucaena in Paraná state, Brazil, for the generation of renewable energy. Two field studies were conducted in the municipality of Ibiporã $\left(23^{\circ} \mathrm{S}, 51^{\circ} 01^{\prime} \mathrm{W}\right)$. In the first study, the dry matter accumulation curves were calculated, with sampling at 30,60,90,120, and 180 days after cultivation. The second study was conducted in a randomized complete block design with split plots. The total aboveground biomass production of elephant grass and leucaena was estimated in the main plot. Cutting times of 60 and 120 days after cultivation were evaluated in the subplots. The productivity of dry matter $\left(\mathrm{kg} \cdot \mathrm{ha}^{-1}\right)$ was estimated using the biomass data. In addition, the potential production of energy from the burning of elephant grass biomass, and the potential production of total aboveground biomass and energy of elephant grass (in Paraná) was estimated using an agrometeorological model. Elephant grass can be potentially used as an alternative energy source. Leucaena has slow initial growth, and it must therefore be evaluated over a longer period in order to determine its potential. Simulation analyses of the capability of power generation, conducted based on the annual dry matter production, revealed that elephant grass could be an important source of renewable energy in the state of Paraná.
\end{abstract}

Key words: Pennisetum purpureum Schumach, Leucaena leucocephala, renewable energy, energy density, potential productivity

\section{Resumo}

O objetivo deste estudo foi avaliar a produção de biomassa de capim elefante e leucena no estado do Paraná visando à geração de energia. Foram conduzidos dois estudos de campo no município de Ibiporã, $\mathrm{PR}\left(23^{\circ} \mathrm{S}, 51^{\circ} 01^{\prime} \mathrm{W}\right)$. No primeiro, determinaram-se as curvas de acúmulo de matéria seca da parte aérea com coletas aos 30,60, 90, 120 e 180 dias após o plantio. No segundo, foi conduzido um experimento em blocos ao acaso, com parcelas subdivididas. Na parcela principal foi avaliada a produção total de biomassa da parte aérea de capim elefante e leucena. Nas subparcelas foram avaliadas as épocas de corte aos 60 e 120 dias de cultivo. Com os dados de biomassa determinaram-se a produtividade total de massa seca da parte aérea $(\mathrm{kg} / \mathrm{ha})$ e o potencial de produção de energia proveniente da queima da biomassa do capim elefante, e fez-se a estimativa da produção potencial de biomassa e energia de capim elefante no Paraná utilizando um modelo agrometeorológico. O capim elefante possui características que possibilitam a sua utilização como fonte alternativa de energia. A leucena possui crescimento inicial lento e, portanto, requer estudos por um período mais prolongado a fim de se determinar o seu potencial.

${ }^{1}$ Biólogas, Mestres em Bioenergia, Universidade Estadual de Londrina, UEL, Londrina, PR, Brasil. E-mail: fernandasa22@ hotmail.com; geoczaro@gmail.com

${ }^{2}$ Eng $^{\mathrm{o}} \mathrm{Agr}^{\mathrm{0}}, \mathrm{PhD}$ Pesquisador Associado do Simepar e Pesquisador Voluntário, IAPAR, Londrina, PR, Brasil. E-mail: pcaramori@ gmail.com

${ }^{3}$ Eng $^{\mathrm{o}} \mathrm{Agr}^{\mathrm{o}}$, Dr. Pesquisador, Empresa de Pesquisa Agropecuária e Extensão Rural de Santa Catarina, EPAGRI/CIRAM, Florianópolis, SC, Brasil. E-mail: wilianricce@epagri.sc.gov.br

${ }^{4}$ Eng $^{\mathrm{O}} \mathrm{Agr}^{\mathrm{o}}$, Dr., Dept ${ }^{\mathrm{o}}$ de Agronomia, UEL, Londrina, PR, Brasil. E-mail: marcoatcosta@hotmail.com

* Author for correspondence 
As análises de simulação de potencialidade de geração de energia, em função da matéria seca produzida anualmente, mostraram que o capim elefante pode se constituir em uma importante fonte de energia renovável no estado do Paraná.

Palavras-chave: Pennisetum purpureum Schumach, Leucaena leucocephala, energia renovável, densidade energética, produtividade potencial

\section{Introduction}

There is no doubt that human activities such as the emission of gases from fossil fuels are a major contributor to global warming (IPCC, 2014). This has led to a large amount of research into the development of alternative energy sources, with an emphasis on the use of plant biomass.

According to the Energy Research Company EPE (2014), the National Energy Balance showed that $7.6 \%$ of Brazil's electricity is obtained from lignocellulosic biomass. This is considered to be one of the major alternatives for the diversification of energy sources and (consequently) reduction of the dependence on fossil fuels in both the international and domestic markets.

The C4 grasses developed for agriculture in Parana, such as elephant grass (Pennisetum purpureum Schumach), have a higher productive potential and lower climate risk compared to grain crops; in addition, this species could add to the income of producers, and help in energy generation on the farm. Elephant grass has a growing potential for cleaner energy production, high biomass production, and atmospheric carbon sequestering (BODDEY et al., 2004). The ability to produce over 40 tons of dry biomass per hectare makes the cultivation of elephant grass an option, and even a solution, for bioenergy programs based on the use of plant biomass (ZANETTI et al., 2010). With such levels of productivity, approximately 700 GJ.ha-1 of energy can be generated for an average gross calorific value of approximately $17,000 \mathrm{KJ} \cdot \mathrm{kg}^{-1}$. The biomass quality from elephant grass is inferior compared to that from other sources, such as sugar cane bagasse (SEYE, 2003) or wood (PEREIRA et al., 2000; BARCELLOS et al., 2005). Therefore, direct burning is the preferential method with which elephant grass can be used, with the possibility of using the resulting ashes for agricultural purposes (FLORES et al., 2012).

Leucaena (Leucaena leucocephala), in addition to having a high biomass production potential, is also a nitrogen-fixing leguminous plant that does not require fertilization with this nutrient. It can also be used in the recovery of degraded areas/regions, green fertilization, wood production, charcoal production, in shading, and windbreaks (SILVA et al., 2007).

According to previous surveys conducted by the Department of Agriculture and Supply of the State of Parana - SEAB - DERAL (2009), much of the wood produced in Parana is consumed in the form of biofuel $\left(3,178,711.5 \mathrm{~m}^{3}\right.$ or $\left.79.18 \%\right)$ for energy production. These are predominantly used through direct combustion or as charcoal.

The state of Parana is characterized by great diversity in climatic conditions, being situated in a tropical to temperate climate transition region, and because it has rugged land (CARAMORI et al., 2001). An $8^{\circ} \mathrm{C}$ decrease in average annual temperature and an $800 \mathrm{~mm}$ increase in total average annual rainfall was observed from the north to the south of the state (CAVIGLIONE et al., 2000). Therefore, any potential study on productivity of plant species must consider the climatic diversity of the state.

Therefore, this study aimed to evaluate the energy productivity of elephant grass and leucaena biomass in the state of Parana. 


\section{Material and Methods}

Elephant grass (P. purpureum Schumach) and leucaena ( $L$. leucocephala) were cultivated on an experimental farm at the Agronomic Institute of Parana - IAPAR in Ibiporã $\left(23^{\circ} \mathrm{S}, 51^{\circ} 01^{\prime} \mathrm{W}\right)$. The area was plowed and fenced; $2 \mathrm{t} \mathrm{ha}^{-1}$ of lime with total neutralizing power of $75.2 \%$ was applied before cultivation, in order to raise the base saturation level to $77 \%$ in the $0-20 \mathrm{~cm}$ layer. This was done to maintain appropriate conditions during the entire growing period.

The leucaena seeds were induced to break dormancy through immersion in water at boiling point for $3 \mathrm{~min}$ (SOUZA, 2005) and were sown in plastic pots.

Plots of elephant grass and leucaena were planted during the second half of October 2012. The cuts of elephant grass were taken in triplicate at intervals of $30,60,90$, and 120 days after plantation, in order to determine the interval that promoted a greater accumulation of total dry matter in the aerial plant parts. The leucaena cuts (triplicate) were taken at the aforementioned intervals; in addition, another set of cuts was at 180 days. All plots had an area of 4 linear meters, and a useful area of $12 \mathrm{~m}^{2}$, distributed randomly throughout the experimental area. Growth curves were constructed for both species for the evaluation period with these data, through simple linear regression analysis using the SigmaPlot software (Systat Software, Inc., San Jose, CA).

A field experiment was implemented using the experimental design in randomized blocks with split plots. The total biomass production was evaluated in the main plot. The cutting times at 60 and 120 days of cultivation were evaluated in the subplots. The following treatments were evaluated: elephant grass cut after 60 days; elephant grass cut after 120 days; leucaena cut after 60 days; leucaena cut after 120 days; elephant grass intercropped with leucaena cut after 60 days, and elephant grass intercropped with leucaena cut after 120 days. The area of each plot was $5 \times 10 \mathrm{~m}$, and the evaluations were conducted in four replications. Four rows each of elephant grass and leucaena were planted for the intercropping experiment. Five lines of each species were planted for the experiments with no intercropping. Three lines of each species were planted for each biomass evaluation experiment, leaving two external lines as the boundary.

Aerial plant parts, consisting of leaves and stems of leucaena and/or elephant grass, were used for both studies. The production of dry biomass was calculated using the ratio of green mass weight (measured in the field) and the dry mass weight of a sub-sample of the material (dried in an oven at $65^{\circ} \mathrm{C}$ to a constant weight).

An automatic weather station was installed to collect daily temperature and precipitation data during the experimentation period; the monthly averages of these factors are listed in Table 1. The plant establishment phase (October and November) showed low precipitation; therefore, so it was necessary to ensure irrigation maintenance to ensure initial uniformity. This was performed using hoses, with 15-mm being applied twice a week during these two months. The potential dry matter production of elephant grass was estimated based on the model proposed by Villa Nova et al. (1999), using representative data from the entire state of Parana. This model is based on photo thermal units, in the absence of moisture stress, with 60-day cutting intervals, according to the equation:

$$
U F=\frac{\left(\frac{n}{2} G D\right)^{\frac{N f}{N i}+1}}{\frac{N f}{N i}+1}
$$


Table 1. Average monthly precipitation ( $\mathrm{mm})$, minimum, average, and maximum temperature, and daily UR.

\begin{tabular}{lcccccc}
\hline Year & Month & $\begin{array}{c}\text { Precipitation } \\
(\mathrm{mm})\end{array}$ & $\begin{array}{c}\text { Min Temp } \\
\left({ }^{\circ} \mathrm{C}\right)\end{array}$ & $\begin{array}{c}\text { Ave. Temp. } \\
\left({ }^{\circ} \mathrm{C}\right)\end{array}$ & $\begin{array}{c}\text { Max Temp } \\
\left({ }^{\circ} \mathrm{C}\right)\end{array}$ & Daily UR $(\%)$ \\
\hline 2012 & Oct & 41 & 19 & 25 & 32 & 62 \\
2012 & Nov & 93 & 19 & 24 & 30 & 65 \\
2012 & Dec & 268 & 21 & 26 & 32 & 73 \\
2013 & Jan & 176 & 19 & 24 & 29 & 75 \\
2013 & Feb & 355 & 20 & 24 & 30 & 80 \\
2013 & Mar & 134 & 19 & 23 & 29 & 76 \\
2013 & Apr & 138 & 17 & 21 & 27 & 74 \\
2013 & May & 140 & 15 & 20 & 25 & 75 \\
2013 & Jun & 212 & 15 & 18 & 23 & 86 \\
2013 & Jul & 34 & 12 & 17 & 23 & 72 \\
2013 & Aug & 0,4 & 12 & 19 & 27 & 58 \\
2013 & Sep & 77 & 15 & 21 & 28 & 64 \\
2013 & Oct & 191 & 17 & 22 & 28 & 64 \\
\hline
\end{tabular}

Where, UF denotes the number of photo thermal units corresponding to $\mathrm{n}$ days of development; GD is the degrees - days average for a period of $n$ days; $\mathrm{Nf}$ is the value denoting the photoperiod (hours) at end of the growth period; and $\mathrm{Ni}$, is the photo period value at the beginning of the growth period. GD is expressed using the following equations:

$$
G D=(T-15) G D=(T-15),
$$

when the minimum air temperature during this period is $>15^{\circ} \mathrm{C}$, which corresponds to the lower base temperature, and

$$
G D=\frac{\left(T_{x} 15\right)^{2}}{2\left(T_{x} T_{m}\right)} G D=\frac{\left(T_{x} 15\right)^{2}}{2\left(T_{x} T_{m}\right)}
$$

when the minimum air temperature is less than $15^{\circ} \mathrm{C}$. Here, $\mathrm{T}_{\mathrm{x}}$ is the average maximum air temperature during the study period; $\mathrm{T}_{\mathrm{m}}$ denotes the average minimum air temperature during this period; and $\mathrm{T}$ indicates the average air temperature for this period, and is calculated as the average of $T_{x}$ and $T_{m}$. The use of a correction value was proposed for when the temperature exceeds $30^{\circ} \mathrm{C}$; however, since this temperature was not reached, the value was deleted from the equation.
The photo period values ( $\mathrm{Ni}$ and $\mathrm{Nf}$ ) were calculated using the equations presented by VarejãoSilva (2006):

$$
\mathrm{N}=2 / 15 \arccos (-\tan \varphi \tan \delta)
$$

Where, $\mathrm{N}$ is the duration of daylight in hours; $\varphi$ is the local latitude (the value is negative for the southern hemisphere); and $\delta$ denotes the declination of the Earth. $\delta$ was calculated using the following formula:

$$
\delta=23.45 \sin [360(284+n) / 365]
$$

Where $\mathrm{n}$ is the Julian date. The values were converted to radians in order to calculate the sine and tangent values.

$$
P=\frac{12,61}{1+e^{2,85-8,133 \times 10^{5}} U F}
$$

Where $\mathrm{P}$ denotes the dry matter production (t.ha ${ }^{1}$ for a 60 -day period), and UF is the photo thermal unit corresponding to the 60 -day period.

In order to determine the potential energy production of elephant grass, the average of the gross calorific value obtained by Zanetti et al. (2010),

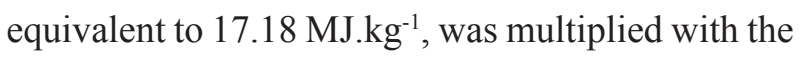
estimated dry matter (P). Flores et al. (2013) also reported a similar average gross calorific value of 17.15 MJ.kg-1 for elephant grass. 


\section{Results and Discussion}

The biomass productivity of elephant grass was determined to be higher than that of leucaena within 120 days after plantation (Table 2). The results demonstrated the low capacity of leucaena for biomass production during the initial growth phase, and at short cutting intervals. The biomass productivity of elephant grass increased during all three cutting intervals, with peak production at (approximately) 90 days, and a tendency for biomass stabilization at (approximately) 120 days of growth (Figure 1). Leucaena displayed a trend for linear increase in dry matter even after 180 days of plantation, indicating the slower growth rate of this species during the initial stages; in fact, the growth rate did not peak during the duration of the study (Figure 2). Teles et al. (2000) highlighted the slow initial growth of leucaena, and recommended seedling plantation in order to ensure better consistency.

Table 2. Accumulated productivity of dry biomass of elephant grass and leucaena ( $\left.\mathrm{kg} \mathrm{ha}^{-1}\right)$, after 30 to 180 days of growth.

\begin{tabular}{ccc}
\hline Species & Cutting interval (days) & $\left(\mathrm{kg} \mathrm{ha}^{-1}\right)$ \\
\hline Elephant grass & 30 & 5502 \\
& 60 & 13205 \\
& 90 & 16272 \\
& 120 & 15454 \\
\hline Leucaena & 30 & 661 \\
& 60 & 1837 \\
& 90 & 3107 \\
& 120 & 2805 \\
\hline
\end{tabular}

Figure 1. Dry matter accumulation $\left(\mathrm{kg} \mathrm{ha}^{-1}\right)$ of elephant grass with the increase in cutting intervals (from 07/02/2013). Ibiporã, PR.

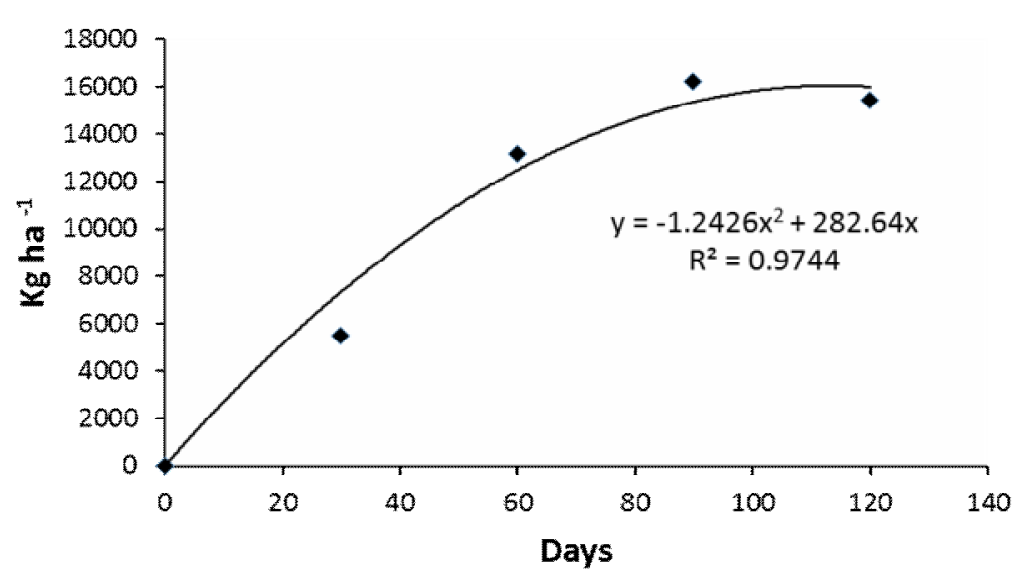


Figure 2. Dry matter accumulation $\left(\mathrm{kg} \mathrm{ha}^{-1}\right)$ of leucaena with the increase in cutting intervals (from 07/02/2013). Ibiporã, PR.

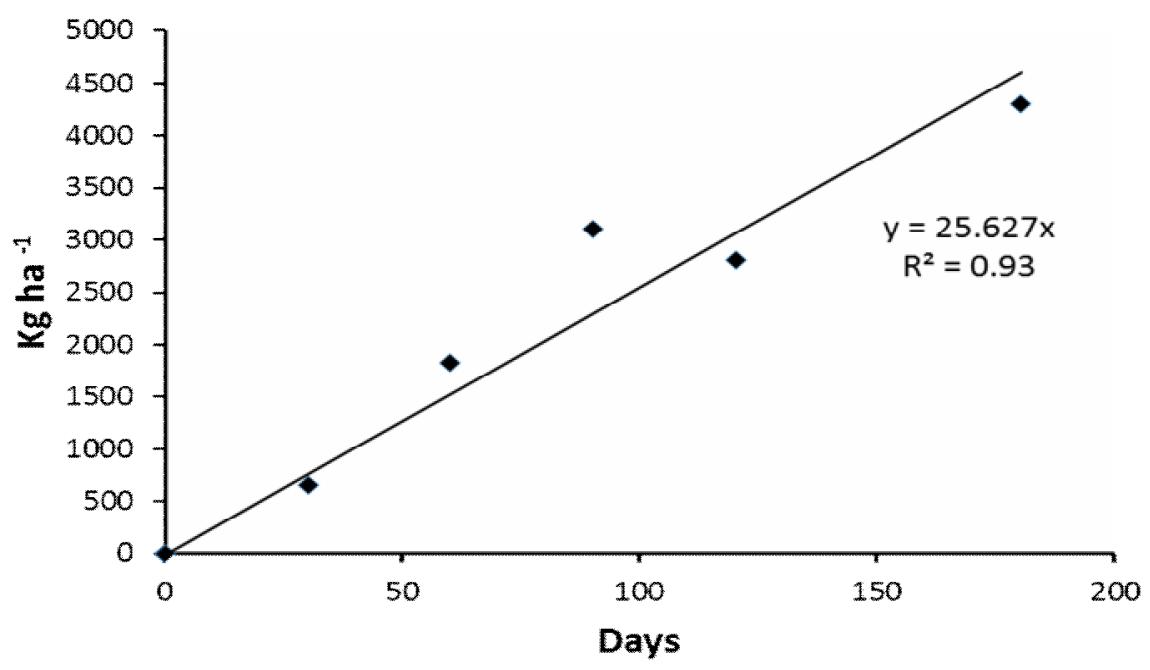

Table 3 details the average dry matter production (DM) of elephant grass and leucaena in isolated and mixed plantations, determined using four cuts at 60-day intervals and two cuts at 120-day intervals. The average DM production estimated from the cuts obtained at 60-day intervals was lower than that of the cuts obtained at 120-day intervals.

Table 3. Dry matter production $\left(\mathrm{kg} \mathrm{ha}^{-1}\right)$ of elephant grass and leucaena from four cuts, at 60 and 120 days.

\begin{tabular}{lrrc}
\hline \multicolumn{1}{c}{ Experiments } & 60 days & 120 days & Average \\
\hline Elephant grass with no & $12,985.06 \mathrm{aB}$ & $27,160.86 \mathrm{aA}$ & $20,072.96$ \\
intercropping & $1,373.14 \mathrm{bA}$ & $2,511.62 \mathrm{bA}$ & $1,942.38$ \\
Leucaena with no intercropping & $11,444.85 \mathrm{aB}$ & $25,125.56 \mathrm{aA}$ & $18,285.21$ \\
Elephant grass + Leucaena & $8,601.02$ & $18,266.01$ & \\
\hline Average & & &
\end{tabular}

C. V. $(\%)=20.89$

Identical letters indicate that there is no difference between the averages using Tukey's test, with a significance level of 5\%. Lowercase letters denote the columns, whereas the uppercase letters denote the rows.

It was observed that biomass of leucaena obtained during the 60- and 120-day cutting intervals did not differ statistically. The elephant grass planted in standalone plots (no intercropping) showed a significant difference between the 60- and 120-day intervals; that is, the cuts obtained after 120 days showed a higher accumulation average compared to those obtained at 60 days.

The DM of elephant grass was observed to be the highest when cultivated with no intercropping, and with an increase in cutting interval; this was observed in previous studies (QUEIROZ FILHO et al., 2000; LEITE et al., 2000). The results obtained in this study are similar to those obtained by Morais et al. (2009), who obtained an average DM of 20.6 t.ha ${ }^{-1}$ using three cuts of the cultivar Cameroon.

It was also observed that leucaena, as well as elephant grass, displayed a higher level of dry matter accumulation at higher cutting intervals, because of the increase in percentage of higher 
density components and reduced water content (COSTA et al., 2007). These results are consistent with the findings of Drumond and Ribaski (2010), who obtained an average DM of 1,250-3,150 kg.ha-1 for leucaena cultivated in Petrolina, Brazil. Lopes et al. (2000), evaluated leucaena that was cut three times at 60-day intervals; two cuts obtained during the rainy season showed an average DM of 3,688 $\mathrm{kg} \cdot \mathrm{ha}^{-1}$, while the one obtained in the dry season showed an average DM of 3,916 kg.ha-1.

Elephant grass intercropped with leucaena showed different productivities compared to Carneiro et al. (2006), who evaluated six cuts (obtained during 60-day intervals over a year) of elephant grass and leucaena, obtaining an average minimum DM of 20.1 t.ha ${ }^{-1}$ and a maximum of 30.3 t.ha ${ }^{-1}$.

The evaluation of dry mass production in grass during different cutting intervals indicated that conditions such as no intercropping and a 120-day cutting interval resulted in the most efficient and productive form of elephant grass. As elephant grass has an annual growth cycle, the potential for biomass production exceeds that of tree species such as eucalyptus and pine, which must be grown for a few years prior to the first cut.

Dry matter production estimates for elephant grass subjected to 60-day cutting intervals in the state of Parana, are shown in Figure 3.
Lower biomass productivity was observed during the months with lower temperatures (from March to August), yielding an approximate dry matter accumulation of 2 to 4 t.ha ${ }^{-1}$. However, dry matter accumulation reached 14 t.ha ${ }^{-1}$ during the warmer months, with the highest production observed in the northwest region of the state, where the temperatures are also higher.

Figure 4 shows the annual elephant grass dry mass production estimate. The state of Parana has a large potential for production of elephant grass throughout the year, especially in the northwest region, with a capacity to produce up to 40 t.ha ${ }^{-1}$ of elephant grass. Villa Nova et al. (1999), who worked on an elephant grass production estimation model for the cultivation of napier grass in Puerto Rico, obtained an estimate of $22 \mathrm{t}^{-\mathrm{ha}^{-1}}$ and $49.88 \mathrm{t}$ $\mathrm{ha}^{-1}$ during the 40-day and 90-day cutting intervals, respectively.

The model estimates reflected the existing thermal diversity in the state of Parana (CAVIGLIONE et al., 2000), exhibiting greater production potential in the areas with lower latitudes and altitudes.

Table 4 details the estimated annual energy density potential of elephant grass in the state of Parana. These values indicate the great potential of elephant grass (source of biomass) for energy production in Parana. This estimate has shown that Parana has the capacity to produce up to 773.8 GJ.ha $^{-1}$ of elephant grass every year, with only 45 t.ha ${ }^{-1}$ of dry mass.

Table 4. Calorific value and energetic density, or amount of available energy from elephant grass, corresponding to dry matter production (DM).

\begin{tabular}{ccc}
\hline Ton MS ha & Mcal $^{\mathbf{1}} \mathbf{a}^{\mathbf{1}}$ & GJ ha $^{\mathbf{1}}$ \\
\hline $\mathbf{5}$ & 20.540 & 85.9 \\
$\mathbf{1 0}$ & 41.080 & 171.9 \\
$\mathbf{1 5}$ & 61.620 & 257.9 \\
$\mathbf{2 0}$ & 82.160 & 343.9 \\
$\mathbf{2 5}$ & 102.700 & 429.9 \\
$\mathbf{3 0}$ & 123.240 & 515.8 \\
$\mathbf{3 5}$ & 143.780 & 687.8 \\
$\mathbf{4 0}$ & 164.320 & 787.8 \\
$\mathbf{4 5}$ & 184.860 & 773.8 \\
\hline
\end{tabular}


Quenó et al. (2011) investigated eucalyptus productivity in different locations, with bi-annual cuts starting at the sixth month; they observed productivities of $448.52 \mathrm{GJ}$ ha $^{-1}$. year-1 with 24 t.ha- ${ }^{-1}$. year $^{-1}$ of biomass, $422.40 \mathrm{GJ}$ ha $^{-1}$. year-1 with 22 t.ha $^{-}$
${ }^{1}$.year ${ }^{-1}$ of biomass, and 384.70 GJ.ha $^{-1}$.year ${ }^{-1}$ with 20 t.ha $^{-1}$.year ${ }^{-1}$ of biomass. Compared to perennial species, elephant grass has the advantage of having an annual growth cycle, enabling faster and more frequent cuts.

Figure 3. Estimate of dry matter production $\left(\mathrm{t} \mathrm{ha}^{-1}\right)$ of elephant grass in the state of Parana.

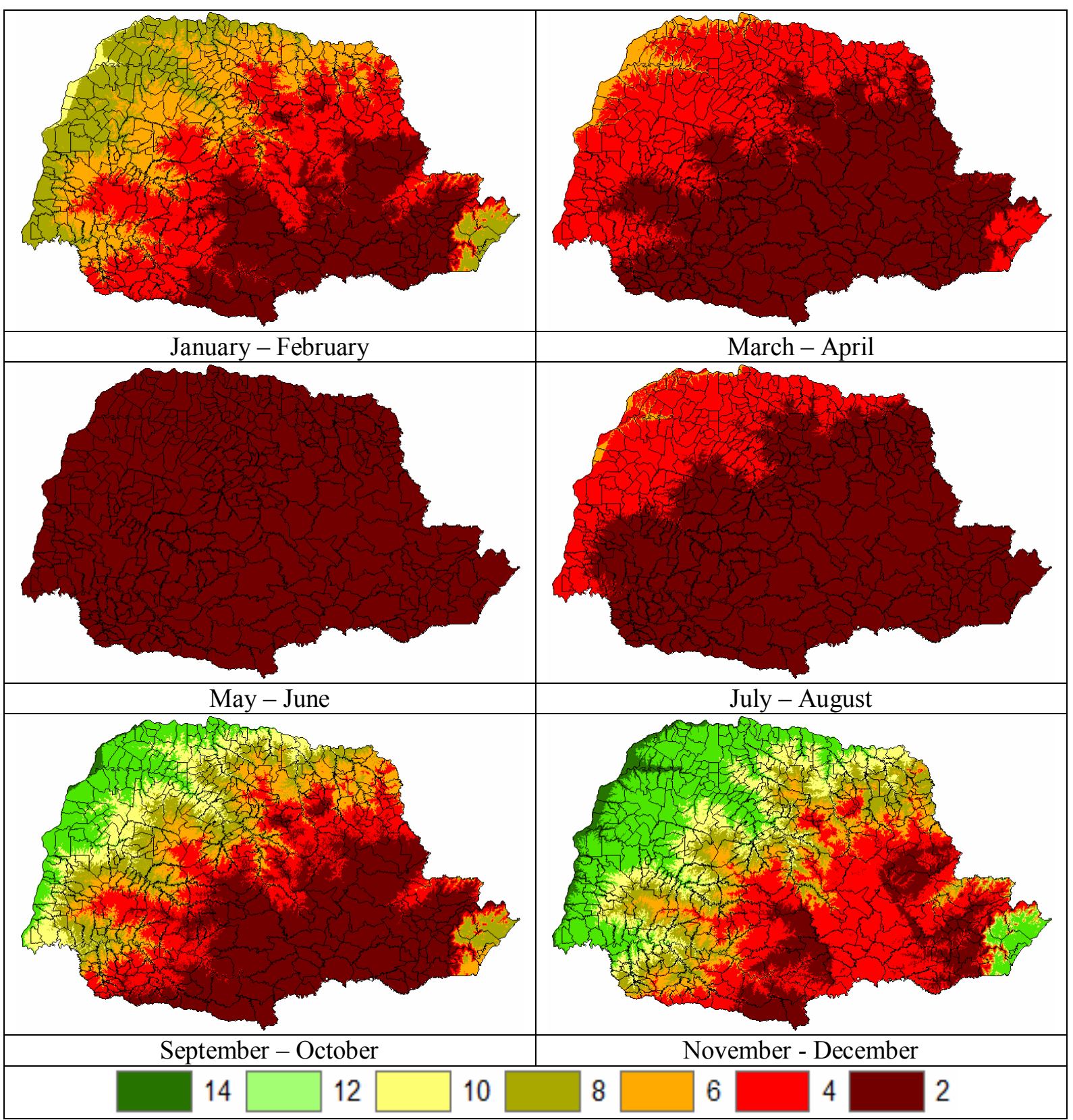


Figure 4. Annual dry matter production $\left(\mathrm{t} \mathrm{ha}^{-1}\right)$ of elephant grass in the state of Parana.

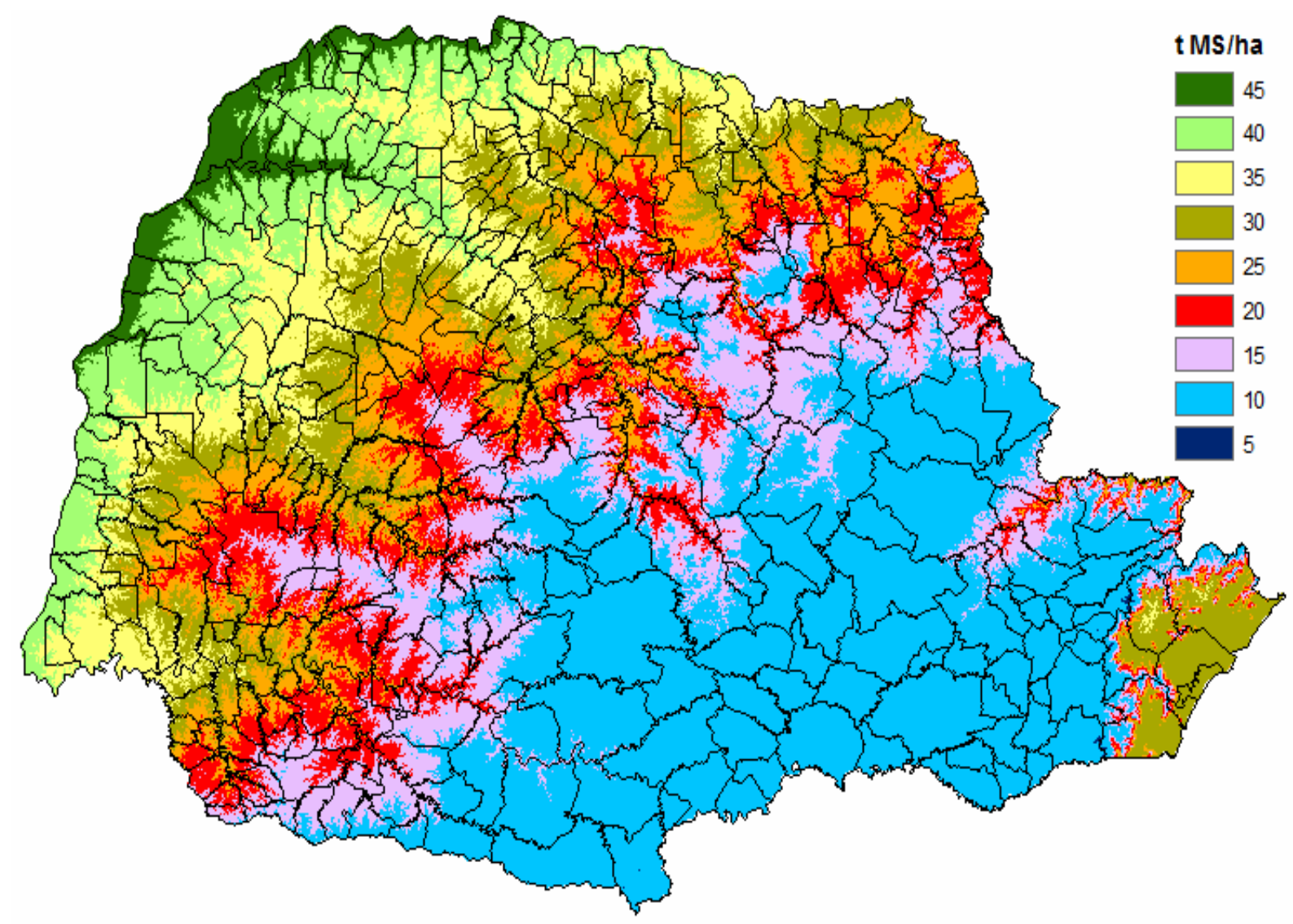

\section{Conclusions}

The production rate of elephant grass cultivated alone was higher than when intercropped with leucaena. The increase in cutting interval (from 60 to 120 days) produced a higher biomass yield.

Leucaena has slow initial growth; therefore, it was not possible to determine its potential during the experimental period.

The predictive analysis for the energy potential as a function of dry matter produced annually showed that elephant grass is a good alternative for the production of renewable energy, especially in the Northern and Western regions of Parana.

\section{Acknowledgements}

To the Agronomic Institute of Parana and its employees, for making this work possible.
To Capes, for the financial support provided to the first author.

\section{References}

BARCELLOS, D. C.; COUTO, L. C.; MÜLLER, M. D.; COUTO, L. O estado-da-arte da madeira de eucalipto para produção de energia: um enfoque nos tratamentos silviculturais. Biomassa \& Energia, São Paulo, v. 2, n. 2, p. 141-158, 2005.

BODDEY, R. M.; MACEDO, R.; TARRÉ, R.; FERREIRA, E.; OLIVEIRA, O. C.; RESENDE, C. de P.; CANTARUTTI, R. B.; PEREIRA, J. M.; ALVES, B. J. R.; URQUIAGA, S. Nitrogen cycling in Brachiaria pasture: the key to understanding the process of pasture decline. Agriculture Ecosytem Environment, Amsterdam, v. 103, n. 2, p. 389-403, 2004.

CARAMORI, P. H.; CAVIGLIONE, J. H.; WREGE, M. S.; GONÇALVES, S. L.; ANDROCIOLI FILHO, A.; SERA, T.; CHAVES, J. C. D.; KOGUISHI, M. S. Zoneamento de riscos climáticos para a cultura do café 
(Coffea arabica L.) no Paraná. Revista Brasileira de Agrometeorologia, Santa Maria, v. 9, n. 3, p. 486-494, 2001.

CARNEIRO, M. S. S.; SOUZA, P. Z.; PEIXOTO, M. J. A.; SALES, R. O.; FEITOSA, J. V. Efeito do consórcio do capim-elefante com leucena na produção de forragem. Revista Caatinga, Fortaleza, v. 19, n. 1, p. 51-55, 2006.

CAVIGLIONE, J. H.; KIIHL, L. R. B.; CARAMORI, P. H.; OlIVEIRA, D. Cartas climáticas do Paraná. Londrina: IAPAR, 2000. CD-ROM.

COSTA, K. A. P.; OLIVEIRA, I. P.; FAQUIN, V.; NEVES, B. P. das; RODRIGUES, C.; SAMPAIO, F. M. T. Intervalo de corte na produção da massa seca e composição químico-bromatológica da Brachiaria brizantha cv. MG-51. Ciência e Agrotecnologia, Lavras, v. 31, n. 4, p. 1197-1202, 2007.

DRUMOND, M. A.; RIBASKI, J. Leucena (Leucaena leucocephala): leguminosa de múltiplo uso para o semiárido brasileiro. Petrolina: EMBRAPA Semiárido, 2010. 8 p. (Circular técnica, 142).

EMPRESA DE PESQUISA ENERGÉTICA - EPE (BRASIL). Balanço Energético Nacional 2014: Ano base 2013 / Empresa de Pesquisa Energética. Rio de Janeiro: EPE, 2014. 288 p. Disponível em: <https://ben.epe.gov. br/downloads/Relatorio_Final_BEN_2014.pdf $>$. Acesso em: 25 out. 2014.

FLORES, R. A.; URQUIAGA, S.; ALVES, B. J. R.; COLLIER, L. S.; BODDEY, R. M. Yield and quality of elephant grass biomass produced in the Cerrados region for bioenergy. Engenharia Agrícola, Jaboticabal, v. 32, n. 5, p. 831-839, 2012.

FLORES, R. A.; URQUIAGA, S.; ALVES, B. J. R.; COLLIER, L. S.; ZANETTI, J. B.; PRADO, R. M. Nitrogênio e idade de corte na qualidade da biomassa de capim-elefante para fins agroenergéticos cultivado em Latossolo. Semina: Ciências Agrarias, Londrina, v. 34, n. 1, p. 127-136, 2013.

INTERGOVERNMENTAL PANNEL ON CLIMATE CHANGE - IPCC. IPCC Fifth assessment synthesis report. Whashington: ONU/OMM, 2014. Available at: $<$ http://www.ipcc.ch/pdf/assessment-report/ar5/syr/ SYR_AR5_SPM.pdf $>$. Accessed at: 25 out. 2014.

LEITE, R. M. B.; QUEIROZ FILHO, J. L.; SILVA, D. S. Produção e valor nutritivo do capim-elefante cultivar cameroon em diferentes idades. Agropecuária Técnica, Areia, v. 21, n. 1, p. 30-39, 2000.

LOPES, W. B.; SILVA, D. S.; PIMENTA FILHO, E. C.; SILVA, R. L.; QUERINO DIAS, J. M. Avaliação morfisiológica da Leucena (Leucaena leucocephala) submetidas a dois espaçamentos em duas épocas. Revista
Cientifica Produção Animal, Recife, v. 2, n. 2, p. 131140, 2000.

MORAIS, R. F.; SOUZA, B. J.; LEITE, J. M.; BARROS SOARES, L. H.; RODRIGUES ALVES, B. J.; BODDEY, R. M.; URQUIAGA, S. Elephant grass genotypes for bioenergy production by direct biomass combustion. Pesquisa Agropecuária Brasileira, Brasília, v. 44, n. 2, p. 133-140, 2009.

PEREIRA, J. C. D.; STURION, J. A.; HIGA, A. R.; HIGA, R. C. V.; SHIMIZU, J. Y. Características da madeira de algumas espécies de eucalipto plantadas no Brasil. Colombo: EMBRAPA Florestas, DC 38, 2000. $113 \mathrm{p}$.

QUEIROZ FILHO, J. L.; SILVA, D. S.; NASCIMENTO, I. S. Produção de matéria seca e qualidade do capimelefante (Pennisetum purpurium Schum.) cultivar Roxo em diferentes idades de corte. Revista Brasileira de Zootecnia, Viçosa, MG, v. 29, n. 1, p. 69-74, 2000.

QUENÓ, L. M.; SOUZA, A. N.; ANGELO, H.; TEIXERA DO VALE, A.; MARTINS, I. S. Custo da produção das biomassas de eucalipto e capim-elefante para energia. Cerne, Lavras, v. 17, n. 3, p. 417-426, 2011.

SECRETARIA DA AGRICULTURA E DO ABASTECIMENTO DO PARANÁ - SEAB - DERAL

- Departamento de Economia Rural. Disponibilidade de madeira para fins energéticos no estado do Paraná, no período de 1997 a 2007. Curitiba: SEAB, 2009. Disponível em: <http://www.agricultura.pr.gov.br/ modules/qas/uploads/2059/madeira_fins_energeticos. pdf $>$. Acesso em: 10 fev. 2014.

SEYE, O. Análise de ciclo de vida aplicada ao processo produtivo de cerâmica estrutural tendo como insumo energético capim-elefante. 2003. Tese (Doutorado em Agronomia) - Universidade Estadual de Campinas, Campinas.

SILVA, L. X.; FIGUEIREDO, M. V. B.; SILVA, G. A.; GOTO, B. T.; OLIVEIRA, J. P.; BURITY, H. A. Fungos micorrízicos arbusculares em áreas de plantio de leucena e sabiá no estado de pernambuco. Revista Árvore, Visoça, MG, v. 31, n. 3, p. 76-82, 2007.

SOUZA, F. B. Leucena: produção e manejo no nordeste brasileiro. Sobral: EMBRAPA, 2005. 8 p. Disponível em: $\quad<$ http://ainfo.cnptia.embrapa.br/digital/bitstream/ item/26734/1/CT-18.pdf $>$. Acesso em: 15 fev. 2014.

TELES, M. M.; ALVES, A. A.; OLIVEIRA, J.C. G.; BEZERRA, A. M. E. Métodos para a quebra da dormência em sementes de leucena (Leucaena leucocephala (Lam.) de Wit). Revista Brasileira de Zootecnia, Viçosa, MG, v. 29, n. 2, p. 387-391, 2000. 
VAREJÃO-SILVA, M. A. Meteorologia e climatologia. Recife: Versão digital 2, 2006. Disponível em: <http:// www.agritempo.gov.br/publish/publicacoes/livros/ meteorologia_e_climatologia_vd2_mar_2006.pdf $>$. Acesso em: 10 fev. 2014.

VILLA NOVA, N. A.; BARIONI, L. G.; PEDREIRA, C. G.; PEREIRA, A. R. Modelo para previsão de produtividade do capim elefante cv. Napier em função da temperatura do ar, fotoperíodo e frequência de desfolha. Revista Brasileira de Agrometeorologia, Santa Maria, v. 7, n. 1, p. 75-79, 1999.

ZANETTI, J. B.; MORAIS, R. F.; ALVES, B. J. R.; BODDEY, R. M.; URQUIAGA, S.; SOARES, L. H. B. Balanço de energia na produção de capim-elefante em condições experimentais. Seropédica: EMBRAPA Agrobiologia, BPD 71, 2010. 24 p. 
